\title{
Karakter Musik Etnik Dan Representasi Identitas Musik Etnik
}

\author{
Sri Hermawati Dwi Arini, Didin Supriadi, Saryanto \\ Universitas Negeri Jakarta \\ Jl. Rawamangun Muka, Jakarta Timur 13220
}

\begin{abstract}
Representation can be identified as the use of signs to illustrate something that is as a music character with elements, among others are playing and doing/processing technique. While, sign is everything that represents something, which is exhibiting of signs such as cengkok, imbal (patterns played by the elaborating instruments in the Javanese gamelan). This is considered as identifying characteristic that represents ethnic music of the Javaness, similarly with the exhibition of signs as ugal, cecandetan and kotekanare are treated as identifying characteristic that represent the identity of Ethnic music of Baliness.
\end{abstract}

Keywords: Identity, Representation, Character, Javaness and Baliness Gamelan.

\begin{abstract}
ABSTRAK
Representasi dapat didefinisikan sebagai penggunaan tanda untuk menggambarkan sesuatu, yakni karakter musik yang memiliki elemen, di antaranya teknik permainan dan garapan/pengolahan. Sedangkan tanda adalah segala sesuatu yang merepresentasikan sesuatu, yakni penampilan tanda-tanda seperti cengkok, imbal. Cengkok, imbal diperlakukan sebagai identitas yang merepresentasikan identitas musik etnik Jawa, begitu pula penampilan tanda-tanda yakni ugal, cecandetan, kotekan diperlakukan sebagai identitas yang merepresentasikan identitas musik etnik Bali.
\end{abstract}

Kata kunci : Identitas, Representasi, Karakter, Gamelan Jawa dan Gamelan Bali

\section{PENDAHULUAN}

Jika berbicara masalah budaya populer, kita tidak akan pernah mene-mukan keaslian budaya. Budaya sudah terfusi, tersinkretisasi dengan elemen-elemen budaya lain. Namun (Faucaulth, 2012) mengatakan bahwa setiap teks dapat ditelusuri dari mana berasal.

Orang Indonesia mempresentasikan dirinya di luar negeri dengan menggunakan batik, terlepas terdapat keanekaragaman motif batik dari berbagai daerah.
Contoh lain representasi, adalah Taman Mini Indonesia Indah yang memiliki simbol-simbol budaya sebagai representasi kebudayaan daerah dan keanekaragaman budaya Indonesia. Hal ini dilakukan pemerintah saat itu untuk menanamkan pemahaman orang Indo-nesia tentang diri mereka sendiri.

Analogi dalam musik dapat diambil contoh saluang, saronen, suling, dapat kita bedakan suara masing-masing alat musik tersebut, dan kita dapat mengenali identi- 
tas etnik asalnya. Begitu pula dengan gamelan Bali, gamelan Jawa dan degung, instrumentasinya serupa, namun masingmasing gamelan memiliki kekhasan. Ketika kita mendengar suara gamelan Bali, musik ini terkesan energik, ketika kita mende-ngar suara degung musik ini terkesan ekspresif, dan ketika kita mendengar musik gamelan Jawa, musik ini terkesan agung.

Musik etnik ini, tidak saja dapat dimainkan pada alat musik tradisi, namun karakter etnik ini dapat pula dimainkan pada alat musik Barat. Contoh lagu "Fragmen" karya Jaya Suprana, nuansa gending Jawa dapat dimainkan pada piano, begitu pula karakter etnik Bali dapat dimainkan pada Bass oleh Balawan, karakter Bali dan Papua dapat dimainkan pula pada alat musik electone.

Identitas dari sebuah musik atau kebudayaan sangat penting bagi suatu bangsa. Musik etnik lahir dari buah interaksi dinamis dengan pelbagai konteks, seperti gamelan Jawa menurut (Supanggah, 2002) berasal dari kesenian keraton. Kesenian keraton ini diangkat sebagai gaya kesenian Jawa baku atau standar, yang digunakan sebagai rujukan masyarakat seni dan sebagai materi ajar yang utama di lembaga-lembaga pendidikan kesenian formal, baik di Indonesia maupun di berbagai lembaga atau perkumpulan-perkumpulan kesenian/karawitan di dunia.

Gaya karawitan di Jawa Tengah terdiri atas beberapa gaya. Namun gaya dua keraton berikut inilah yang dijadikan standar, yaitu gaya Surakarta dan gaya Yogyakarta. Gaya Surakarta atau gaya Solo terdapat di dua keraton yakni Kasunanan (Selatan) dan Mangkunegaran (Utara). Gaya karawitan Jawa dianggap agung karena dahulu gamelan difungsikan untuk upacara-upacara di keraton.
Berbeda dengan gamelan Jawa, gamelan Bali memiliki tiga puluh tiga gamelan. Menurut (Sukerta, 2001), di Bali, gamelan berfungsi sebagai pemberi suasana religius. Faktor inilah yang melatarbelakangi karakter gamelan Bali. Identitas pada dasarnya bersifat rela-sional, yang dapat diartikan berupa relasi kesamaan dan perbedaan (Lono Simatupang, 2015).

Dari latar belakang di atas, tampak bahwa hal ini sangat menarik untuk dikaji. Bagaimana karakter gamelan Jawa dan gamelan Bali merepresentasikan identitas etniknya?

\section{METODE}

Metode yang digunakan dalam penelitian ini adalah kualitatif interpretative, dengan teknik pengumpulan data studi pustaka dan wawancara dengan pakar karawitan Bali dan Jawa dari RRI Jakarta. Interpretasi, merupakan penafsiran terhadap fakta dari sumber, dengan mengadakan triangulasi sumber data. Tahap interpretasi ini, dilakukan dalam dua bentuk analisis dan sintesis dengan menggunakan teori.

Teori yang berkaitan sebagai pisau analisis antara lain pengkajian atau analisis musikal pada dasarnya dapat dilihat dari banyak hal, salah satunya adalah dari karakter. Menurut Supanggah (2002), elemen karater/gaya adalah instrumentasi, laras, teknik permainan dan garapan/pengolahan yang dapat dikatakan sebagai cita rasa.

Berkaitan dengan karakter adalah garapan adalah kreativitas pengrawit dalam membuat variasi tabuhan. Dalam garapan ada dua konsep yang penting yakni variasi dan kaitmengait. Membuat variasi dan kait-mengait adalah berbicara tentang cita-rasa. Variasi dan kait- mengait antara gaya gamelan Jawa dan Bali memi- 
liki perbedaan. Perbedaan ini merupakan identitas.

\section{Identitas}

Identitas terbagi menjadi identitas kelompok, identitas suku/etnik, dan identitas nasional. Identitas nasional adalah interpretasi atas pola nilai, simbol, dan tradisi yang membentuk warisan bangsa yang unik, serta identitas individu dengan pola dan warisan tersebut beserta unsur-unsur budayanya (Wacana Jurnal Ilmu Pengetahuan Budaya UI, 2005).

Musik etnik, menurut Lono Simatupang (2011) adalah musik nonwestern atau musik tradisi yang pentatonik, sebagai ekspresi budaya, suatu kelompok etnik berupa peng-organisasian bunyi. Ekspresi melibatkan instrumentasi, teknik permainan, dan citarasa.

Representasi (Marcel Danesi, 2004) dapat didefinisikan sebagai penggunaan tanda untuk menghubungkan/meng-gambarkan sesuatu, sedangkan tanda adalah segala sesuatu yang merepresentasikan sesuatu. Jika digambarkan seperti pada bagan.
Penampilan tanda-tanda ini diperlakukan sebagai identitas yang merepresentasikan identitas etnik. Hal yang sama dikatakan oleh Piere (Lono Simatupang, 2011) bahwa hubungan antara tanda dan yang diwakilinya adalah hubungan simbol merujuk pada hubungan keterkaitan tanda dan yang diwakilinya

\section{HASIL DAN PEMBAHASAN}

Pembahasan karakter adalah ber-bicara sumber bunyi (instrumentasi), laras, teknik permainan, dan citarasa. Namun yang akan dibahas dalam hal ini adalah perbedaan yang merupakan identitas, instrumentasi tidak dibahas karena bentuk dan bahan alat musik gamelan Jawa dan Bali memiliki kesamaan.

\section{Titilaras}

Dalam seni musik karawitan, titila-ras memegang peranan yang penting, sebab dengan menggunakan titilaras kita dapat mencatat, mempelajari, dan menyimpan lagu yang sudah dinotasikan untuk dapat dipelajari dari generasi ke generasi.

Tanda

Identitas

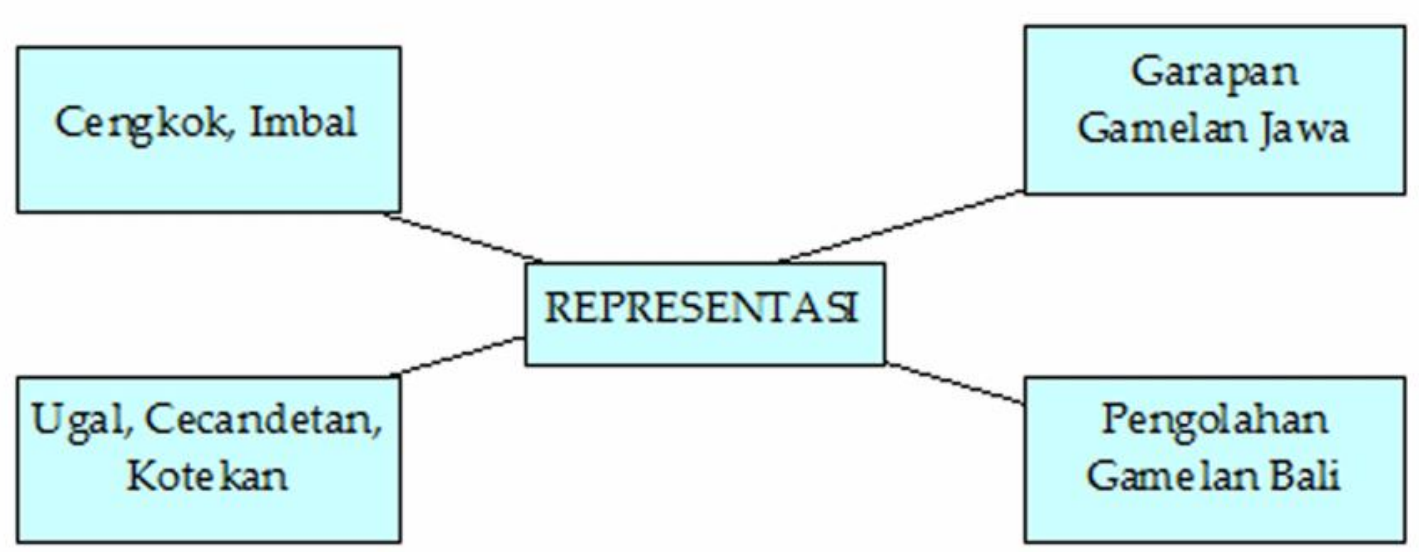

Bagan 1.

Metode Analisis 
Titilaras kepatihan (notasi musik Jawa), dibuat tahun 1910 oleh Kanjeng R.M. Haryo Wreksadiningrat di Keraton Surakarta dengan penyebutan ji ro lu mo nem (Rahayu Supanggah, 2002).

Titilaras ding-dong (notasi musik Bali), dibuat oleh pegawai di Singhamandawa $896 \mathrm{M}$, tidak berupa angka, tetapi berupa lambang (つ), ( ( ), ( D ), ( \ ), ( ○)/dong, deng, dung, dang, ding yang digunakan untuk mencatat dan mempelajari gambelan Bali (I Made Bandem, 1983).

Adapun yang dimaksud laras pentatonik yaitu susunan nada yang memiliki 5 nada, jarak nadanya tergantung dari laras dan patetnya.

Dalam pembahasan ini, untuk memudahkan pemahaman dan penyamaan konsep, akan digunakan notasi angka dan analogi musik diatonis.

Pembahasan ini hanya menjelaskan perbedaan, dalam hal ini perbedaan titilaras, teknik menabuh, dan garapan/ pengolahan.

\section{Gamelan Jawa}

Laras karawitan Jawa adalah sebagai berikut:

Slendro: urutan lima nada yang memiliki pola jarak yang hampir sama.

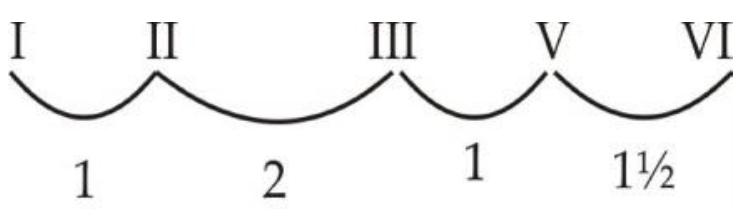

$$
\begin{aligned}
& \text { (200 cent) (400 cent) (200 cent) (300 cent) } \\
& \text { ji ro lu mo nem }
\end{aligned}
$$

Nada-nada dan penyebutan dalam laras gamelan Jawa adalah:

- Penunggul/bonang diberi simbol I, : disebut $j i$

- Gulu diberi simbol II: disebut ro

- Dhadha diberi simbol III: disebut lu
- Lima diberi simbol V: d: disebut ma

- Nem diberi simbol VI: disebut nem

Pelog : Urutan lima atau tujuh nada yang memiliki pola jarak nada yang tidak sama.

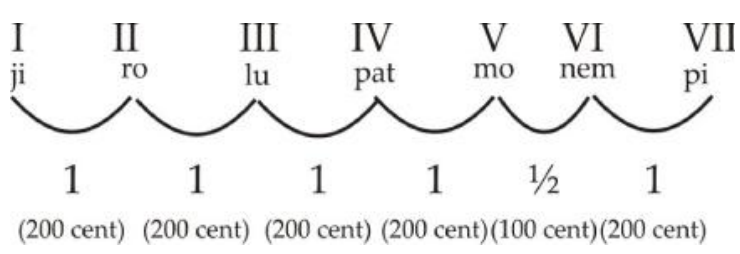

Ada pelog tujuh nada dan lima nada. Jika pelog yang dipergunakan adalah lima nada, nada yang tidak dipakai adalah nada ke VI (pat) dan ke VII (pi) (Sumber: Rahayu Supanggah).

\section{Titilaras gamelan Bali}

Notasi musik Bali menggunakan:

\section{( J), ( 7), (D), ( \), ( ( )$$
\begin{array}{lllll}
1 & 2 & 3 & 5 & 6
\end{array}
$$$$
\text { ding dong deng dung dang }
$$

Laras pelog memiliki interval

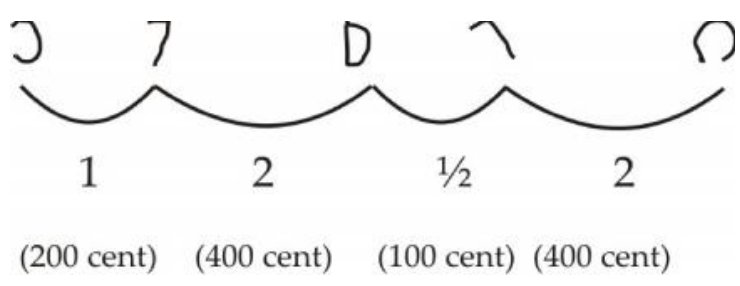

\section{Laras pelog terdiri dari dua macam laras}

1. Laras pelog panca nada yang terdiri dari susunan nadanya

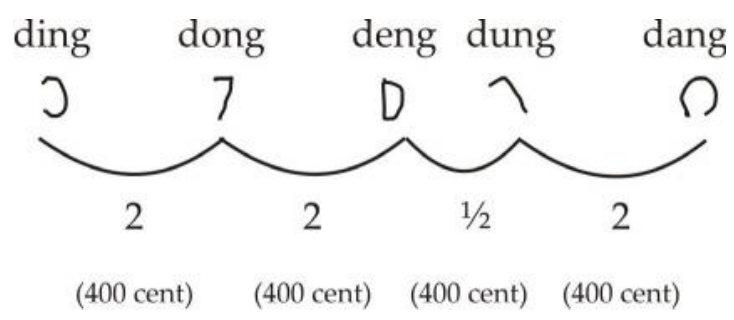


2. Laras pelog sapta nada yang terdiri dari susunan nadanya

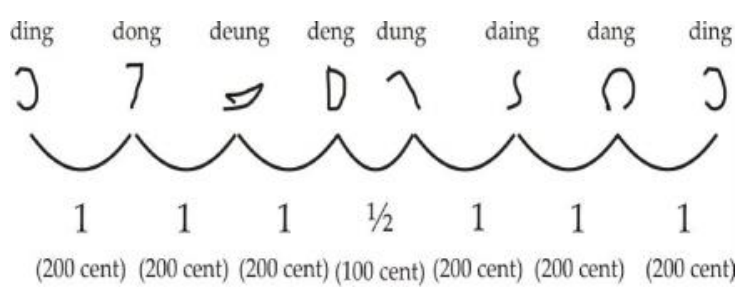

\section{Laras Slendro}

Urutan nada-nada dalam 1 oktaf yang mempunyai interval jarak.

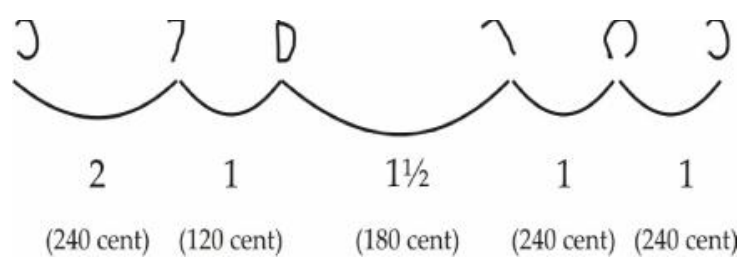

Sumber : I Gusti Bagus Arsaja)

Persamaan garapan/pengolahan antara gamelan Jawa dan gamelan Bali

Garapan/pengolahan bermakna perubahan yang disebut variasi. Pangrawit dapat mengubah melodi dan irama sesuai dengan citarasa.

Ada beberapa macam pengertian variasi yakni variasi mekanis dan variasi pilihan.

Variasi mekanis adalah mengubah melodi dan irama berdasarkan aturan, contoh:

\begin{tabular}{|c|c|c|c|c|}
\hline \multicolumn{5}{|l|}{ Repetisi } \\
\hline Nada pelog & 3 & 5 & 3 & 2 \\
\hline Variasi & 33 & 55 & 33 & 22 \\
\hline \multicolumn{5}{|l|}{ Contoh lain } \\
\hline \multicolumn{5}{|l|}{ Penyisipan } \\
\hline Nada pokok & 3 & 5 & 3 & \\
\hline Variasi & 13 & 15 & 15 & 12 \\
\hline \multicolumn{5}{|l|}{ Contoh lain : } \\
\hline Nada pokok & $<2$ & 3 & 5 & 6 \\
\hline Variasi & 2233 & 2233 & 5566 & 5566 \\
\hline
\end{tabular}

Sedangkan variasi pilihan adalah mengubah irama, tempo dan menambah hiasan pada melodi.

\section{Gamelan Jawa}

Pada gamelan Jawa terdapat pukulan variasi pilihan yang disebut cengkok.

\section{Cengkok}

Cengkok bukan saja untuk tembang melainkan juga terdapat pada permainan gamelan. Pakemnya adalah variasi yang dipilih harus bertemu dengan melodi pokoknya atau berakhir bersamaan dengan melodi pokok.

\section{Garapan/Pengolahan}

Variasi Pilihan

Di bawah ini satu contoh cengkok yang dimainkan pada saron/gender.

[Gender] $\begin{array}{llll}2 & 3 & 2 & 1\end{array}$

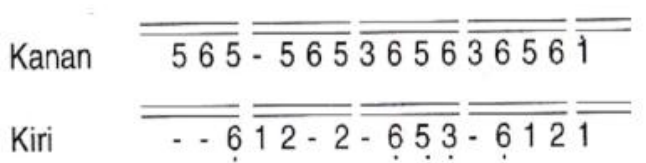

Hiasan bergantung pada laras (tangga nada) dan pathet (modus atau karakter

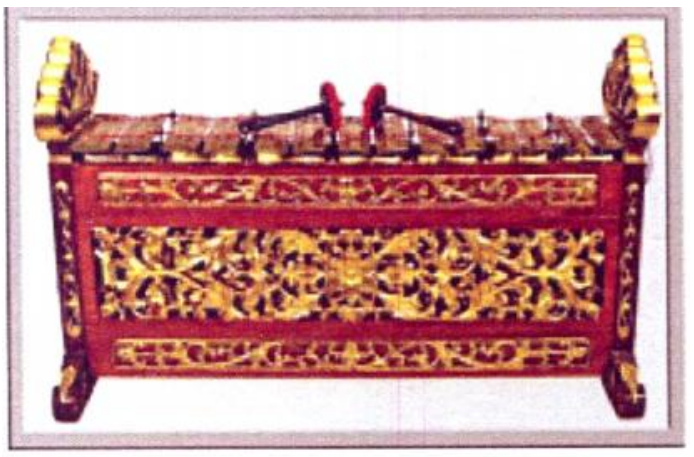

Gambar 1.

Gender, Sumber: Central Javanese gamelan instruments (From JT Titon [ed.]. Worlds of Music 235) 
tangga nada) yang berlaku dalam gendhing (komposisi) yang sedang dimainkan; bisa juga bergantung pada fungsi dan kegunaan gendhing yang sedang dimainkan; bisa tergantung pada konteks lingkungan, waktu, dan tempat; dan bisa bergantung pada selera pribadi dan latar belakang pendidikan pemusiknya.

Teknik yang harus dikuasai oleh sebuah pengrawit Jawa adalah memithet yakni meredam bunyi yang baru saja ditabuh, juga meredam bunyi bersamaan ketika menabuh.

\section{Gamelan Bali}

Contoh variasi pilihan adalah ugal. ugal dimainkan pada alat musik trompong.

Ugal menghiasi lagu pokok dengan tambahan atau perubahan ritmis, namun pada nada akhir pada setiap gatra harus sama dengan nada pokok.

\section{Contoh lain}

Gatra adalah satuan atau unit yang merupakan bagian dari gending, merupakan kalimat lagu.

\section{Teknik Menabuh Gamelan Bali}

1. Pukulan Keklenyongan

2. Pukulan Nyacah

3. Pukulan Cecandetan

\section{Pukulan Keklenyongan}

Pukulan Keklenyongan, teknik pukulan bersama alat musik wilahan, berirama lambat, tempo tidak tetap, namun tidak mengubah irama.

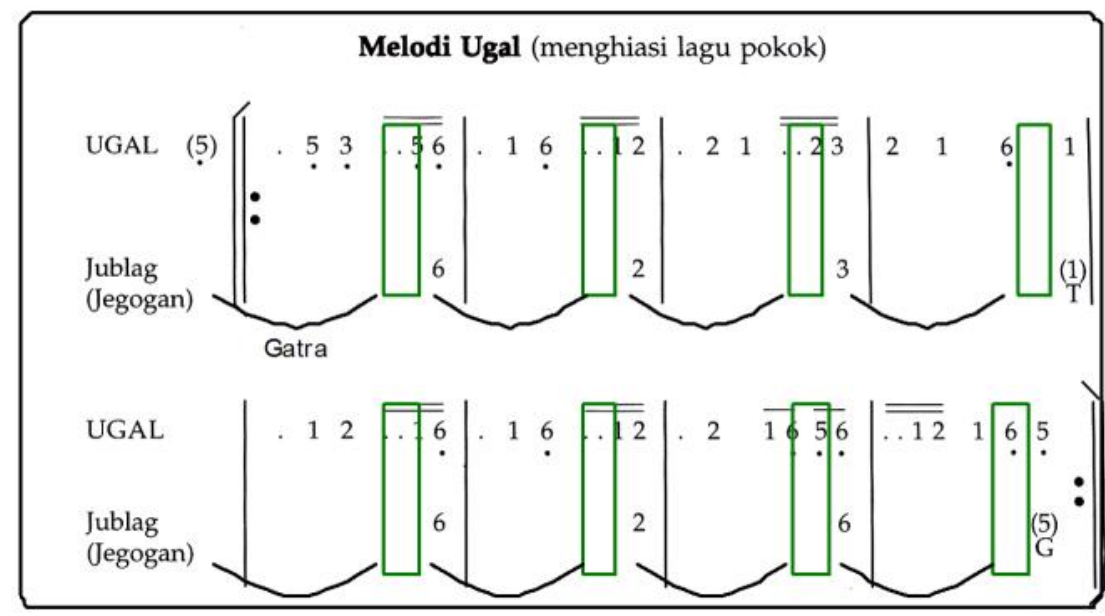

(Sumber : Buku Gong LPSN)

$\mathrm{T}$ : Kentong

$\mathrm{G}$ : Gong

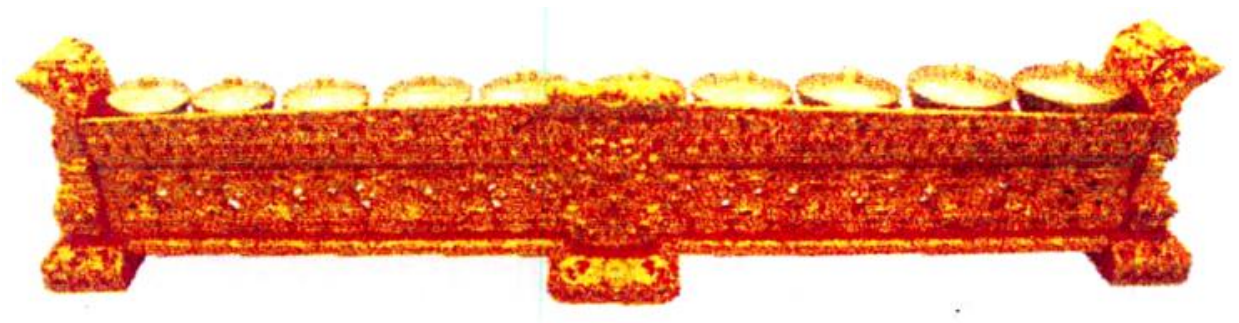

Gambar 2. Trompong 


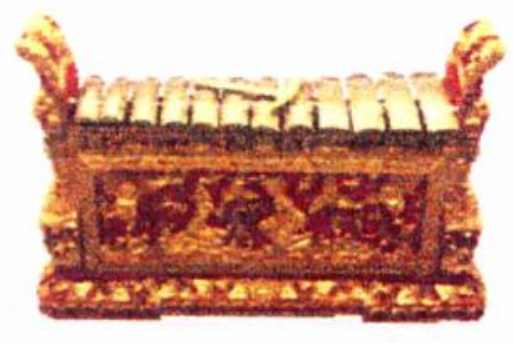

Gambar 3. Pemade

2. Pukulan Nyacah

Pukulan nyacah, teknik pukulan bersama alat musik wilahan, namun mengubah irama dengan repetisi nada, setiap ketukan mendapat satu pukulan nyacah.

\section{Pukulan Cecandetan}

Pukulan cecandetan adalah pukulan melodi pemade, ada macam-macam pukulan cedendetan.

\section{Cecandetan}

Adalah bermacam-macam variasi pada instrumen pemade.

Macam-macam Cecandetan
a. Pukulan cecandetan Nedet
b. Pukulan cecandetan Cek Megelut
c. Pukulan cecandetan Ubit-ubitan
d. Pukulan cecandetan Ngucek

a. Cecandetan Nedet

Adalah pada hitungan ketiga diisi oleh pukulan penghias pada nada sampirannya atau pada hitungan keempat diisi oleh pukulan polos.

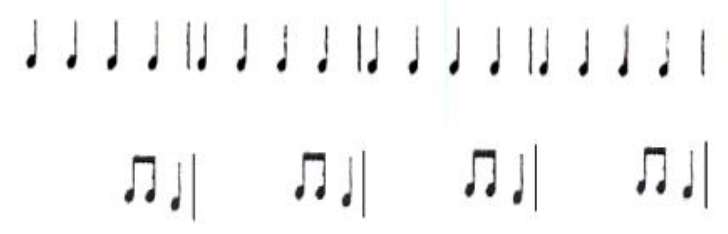

b. Cecandetan Cek Megelut (Sinkop)

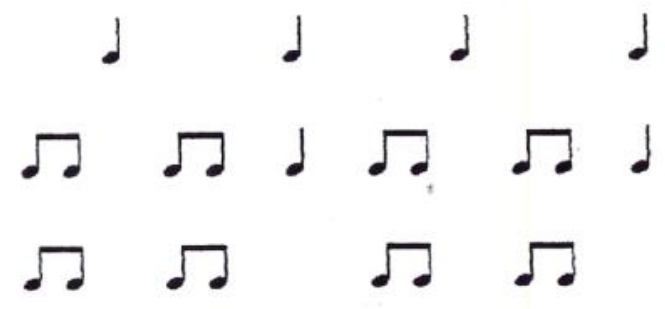

c. Cecandetan Ubit-ubitan

Dimainkan pada Pemade ataupun Reyong pada nada yang sama, setiap bar atau birama diberi not sisipan, sinkop, istilah bar/birama dalam musik tradisi adalah gatra.

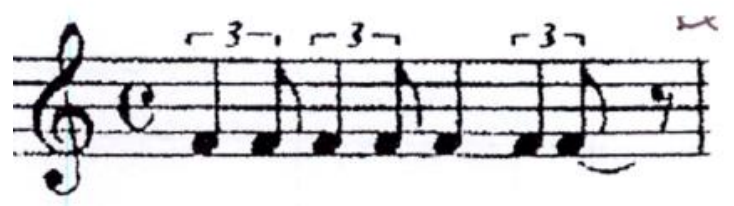

d. Cecandetan ngucek: dimainkan dengan tempo cepat sekali

\section{Teknik Menabuh Gamelan Jawa}

Alat Musik Gender

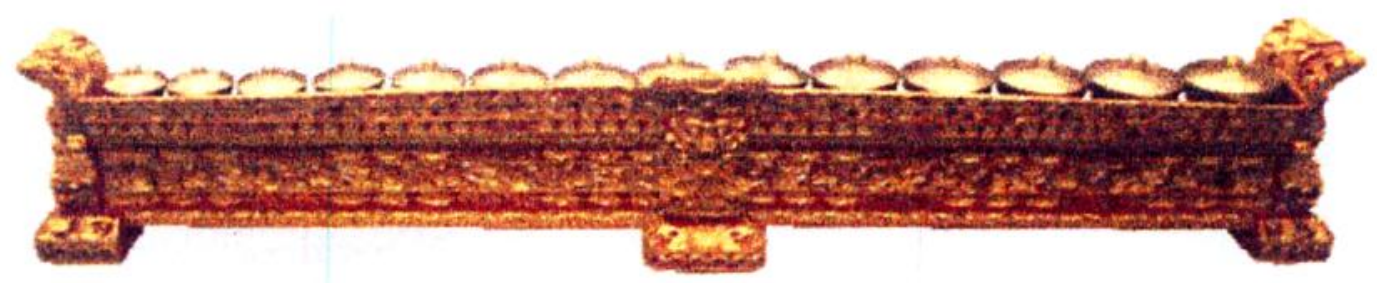

Gambar 4. Reyong

(Sumber Gambar 1, 2, 3: www.anakswarasanti.com/images/ instrument/gamelan/jpg) 


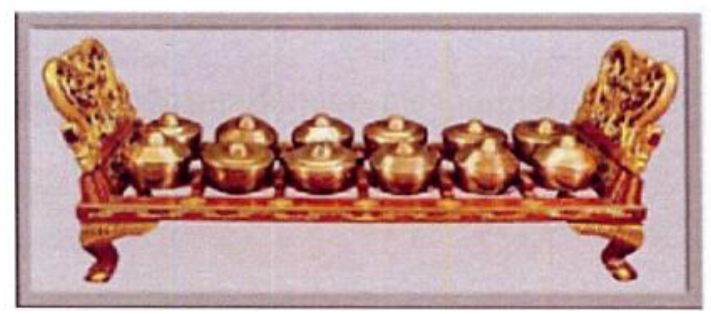

Gambar 5: Bonang

Sumber : Ratihgroup.com

- Tabuhan gembyungan: tangan kanan dan tangan kiri masing-masing memainkan melodi yang berbeda

- Tabuhan kempyung: tabuhan mengapit dua nada

- Tabuhan pendawan: tabuhan mengapit tiga nada

- Tabungan gembyang: tabuhan mengapit empat nada

- Tabuhan samparan: menabuh dua nada dengan cara menyaruk

- Tabuhan ukel: menabuh beberapa nada dengan naik turun pada suatu wilayah nada tertentu.

\section{Garapan/Pengolahan \\ Kait-mengait (Interlocking)}

Teknik untuk menghasilkan kesatuan musik yang lebih cepat, lebih rumit, dan lebih ekspresif dengan cara:

1. Dapat dimainkan pada alat musik yang sama, artinya satu waditra/alat musik dimainkan oleh dua orang sampai empat orang.

2. Permainan dapat pula dimainkan pada alat musik sejenis, artinya satu waditra dimainkan oleh satu pengrawit.

\section{Gamelan Jawa \\ Imbal}

Teknik kait-mengkait ketat dalam gamelan Jawa disebut Imbal. Imbal adalah teknik mengambil serangkaian nada lalu membagi rata nada-nada tersebut. Polanya adalah nada yang jatuh pada mat utama dimainkan pada alat musik A dan semua nada yang jatuh di antara mat utama dimainkan pada alat musik B namun sejenis.

Namun berbeda dengan Bali, yang memiliki tempo permainan yang cepat

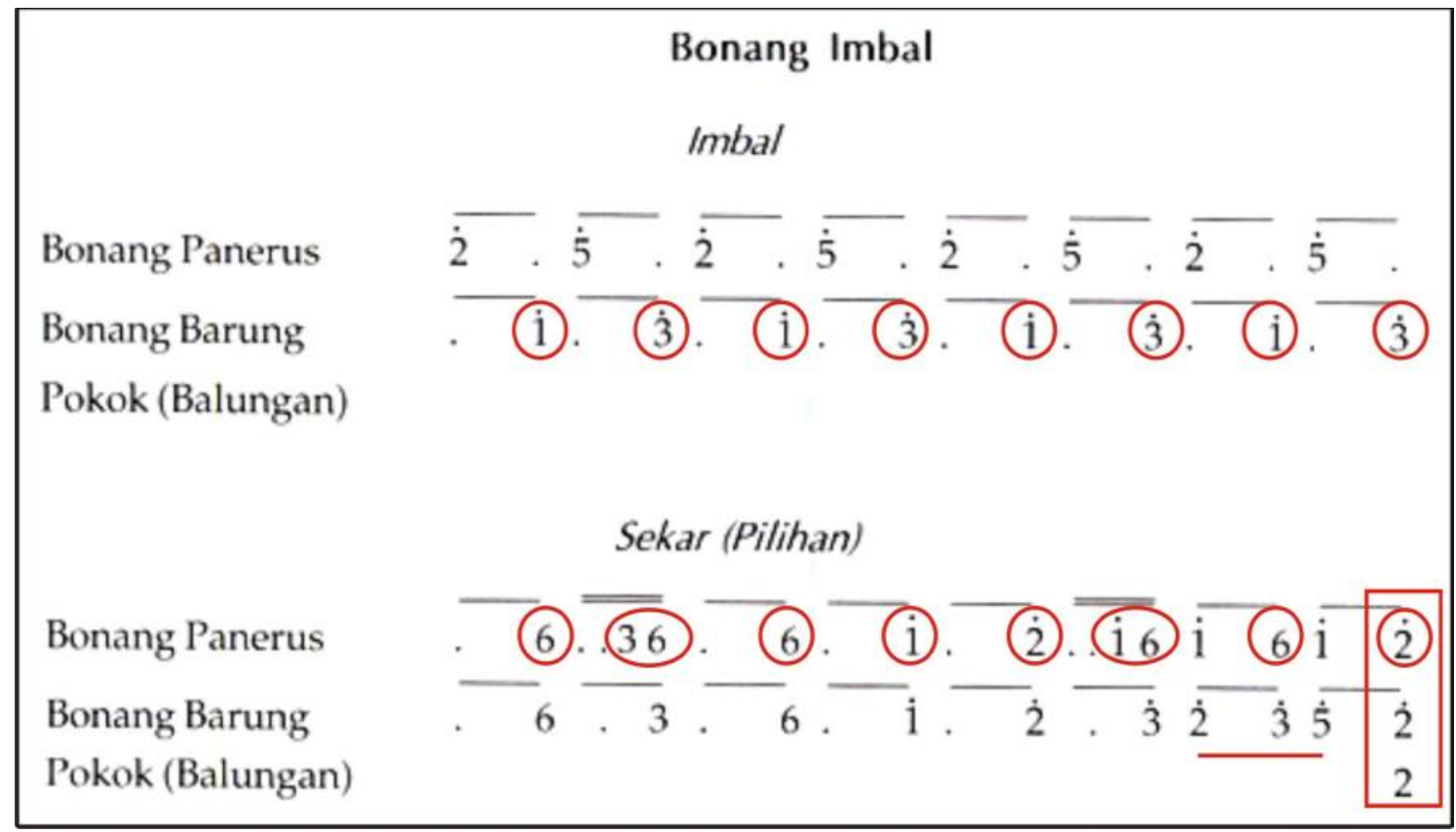

(Sumber : Gong Buku PSN) 


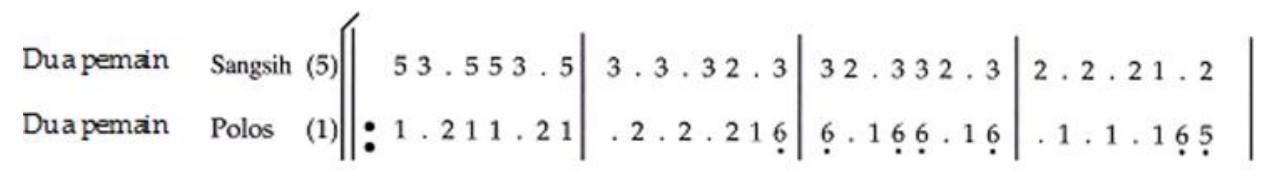

\begin{tabular}{ll|l|l|l|l|} 
Dua pemain & Sangsih & 21.221 .2 & 3.3 .32 .3 & 32.332 .3 & 5.5 .53 .5 \\
Dua pemain & Polos & 5.655 .65 & .2 .2 .216 & 6.166 .16 & $.3 .3 .321:$
\end{tabular}

(Sumber : Gong Buku PSN)

Tabel 1: Representasi Identitas

\begin{tabular}{ll}
\hline Jenis : Tanda & \multicolumn{1}{c}{$\begin{array}{c}\text { Hubungan Antara Tanda dan } \\
\text { Sumber Acuan }\end{array}$} \\
\hline Simbol & $\begin{array}{l}\text { Tanda yang dirancang untuk mengandikan } \\
\text { sumber acuan melalui kesepakatan atau } \\
\text { persetujuan }\end{array}$ \\
\hline
\end{tabular}

Sumber : Marcel Danesi

sekali, pada Jawa Imbal dimainkan pada tempo yang sangat lambat.

Imbal mengisi kekosongan, dan menjelang nada balungan selanjutnya, pemain memilih hiasan supaya bisa bertemu dengan nada balungan. Seperti halnya teori musik barat, nenek moyang kita pun memiliki pemikiran yang serupa, misal pada musik barat, lagu berakhir pada tonika. Pada gamelan, nada berakhir pada nada pokok dalam istilah diatonis adalah tonika atau do.

\section{Kotekan}

Pada musik Bali, teknik kait-mengkait atau kotekan merupakan unsur yang sangat menonjol, dimainkan cepat sekali. Kotekan dimainkan pada pemade, tetapi dapat dimainkan juga pada kantilan.

Kadang-kadang kotekan bukan merupakan variasi, melainkan seperti interlude sebagai bagian khusus di tengah komposisi besar (gending)/ komposisi keseluruhan permainan gamelan.

Permainan kotekan seperti ini biasanya dimainkan pada reyong oleh empat pemain, dua pemain membawakan polos dan dua pemain membawakan (kedua paruh) melodi yang disebut sangsih permainan kotekan harus bertemu/ ber-

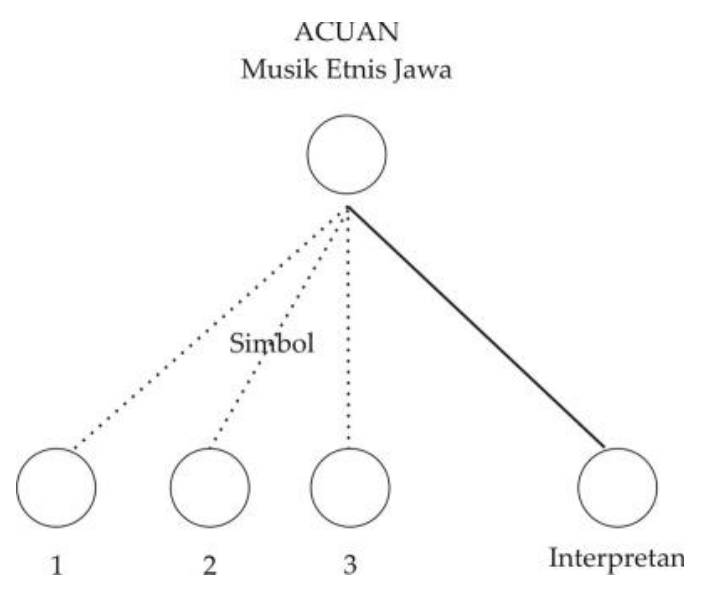


akhir dengan nada pokok atau dalam istilah musik diatonis adalah tonika atau do.

Misal:

Tanda

$\begin{array}{lll}1 & : & \text { Titilaras Jawa } \\ 2 & : & \text { Laras Jawa } \\ 3 & : & \text { Garapan }\end{array}$

\section{Titilaras Jawa}

Slendro: urutan lima nada yang memiliki pola jarak yang hampir sama.

$\begin{array}{lllll}\text { I } & \text { II } & \text { III } & \text { V } & \text { VI } \\ \text { ji } & \text { ro } & \text { lu } & \text { mo } & \text { nem }\end{array}$

Pelog : Urutan lima atau tujuh nada yang memiliki pola jarak nada yang tidak sama.

$\begin{array}{ccccccc}\text { I } & \text { II } & \text { III } & \text { IV } & \text { V } & \text { VI } & \text { VII } \\ \text { ji } & \text { ro } & \text { lu } & \text { pat } & \text { mo } & \text { nem } & \text { pi }\end{array}$

\section{Laras}

Slendro: urutan lima nada yang memiliki pola jarak yang hampir sama.

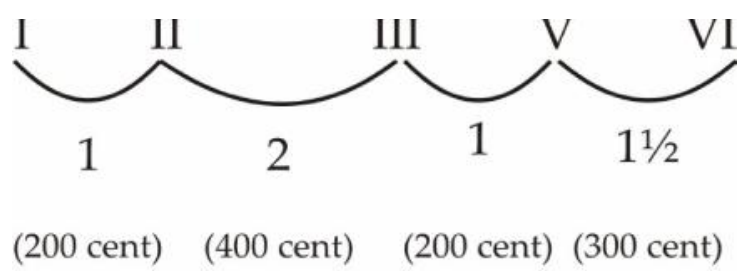

Pelog : Urutan lima atau tujuh nada yang memiliki pola jarak nada yang tidak sama.

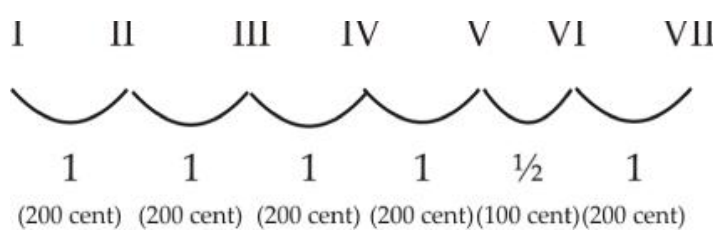

\section{Garapan}

Imbal, Cengkok

Jadi dapat diinterpretasikan mengutip Rahayu Supanggah (2002) dalam tulisannya dalam Buku Bothekan I menyebutkan bahwa, dari karawitan-karawitan di Jawa terdapat gaya Yogyakarta dan Surakarta, ada juga gaya Semarang dan gaya Banyumasan, namun semua mengacu pada gaya Yogyakarta dan Surakarta dan memiliki kesamaan pada titilaras, laras dan teknik menabuh.

Kesamaan pada unsur-unsur inilah yang menunjukkan representasi identitas etnik Jawa (Eriksen, 1993 dalam Lono Simatupang, 2013) yang mengatakan bahwa penegasan identitas berupa onjolan beberapa ciri-ciri, sementara ciri-ciri lain yakni garapan/pengolahan diabaikan atau bahkan direduksi.

Hasil tringulasi sumber data dengan pakar, menjelaskan bahwa sekolah-sekolah formal di tanah Jawa melalui kearifan lokal mempelajari musik karawitan yang standar yang mengacu dari sumber gamelan yogyakarta dan Surakarta.

Misal:

Tanda 1 : Titilaras Bali

2 : Laras Bali

3 : Pengolahan

Notasi musik Bali menggunakan:

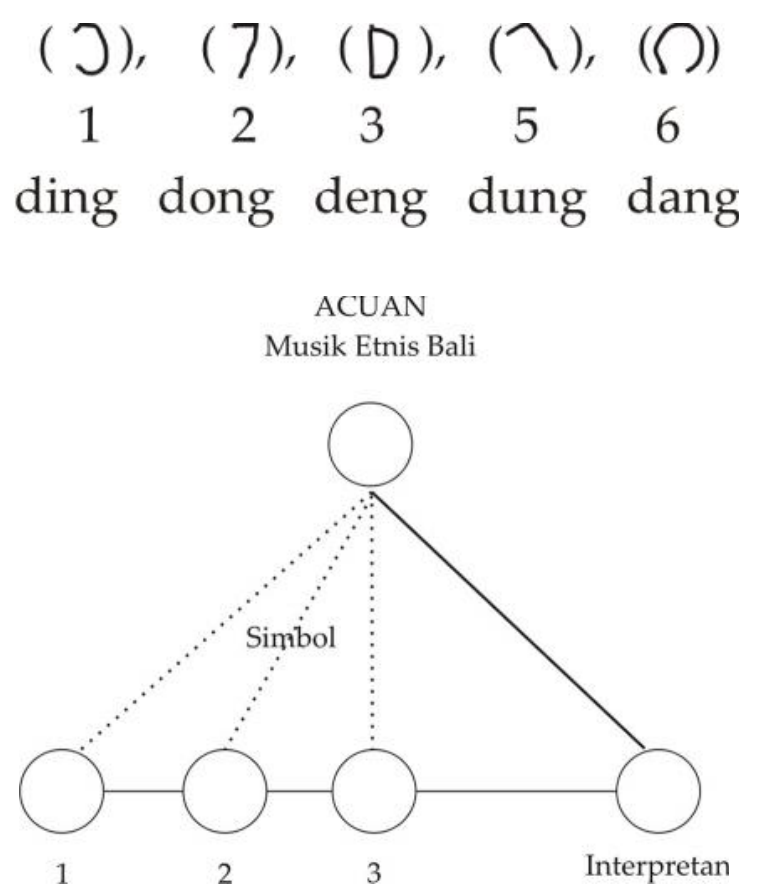


Laras pelog memiliki interval

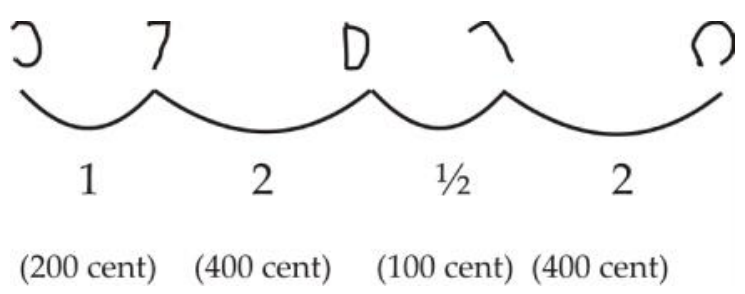

Laras pelog terdiri dari dua macam laras

1. Laras pelog panca nada yang terdiri dari susunan nadanya.

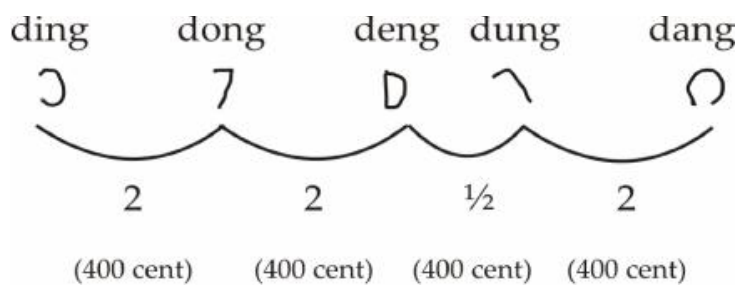

2. Laras pelog sapta nada yang terdiri dari susunan nadanya

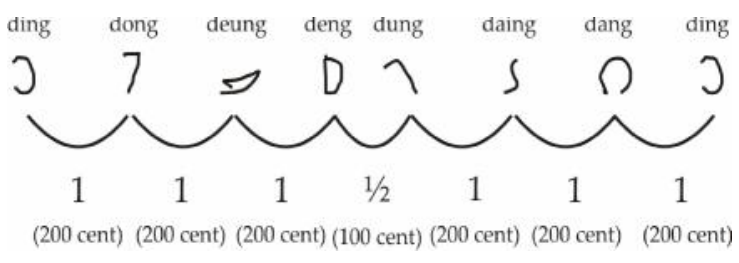

\section{Laras Slendro}

Urutan nada-nada dalam 1 oktaf yang mempunyai interval jarak.

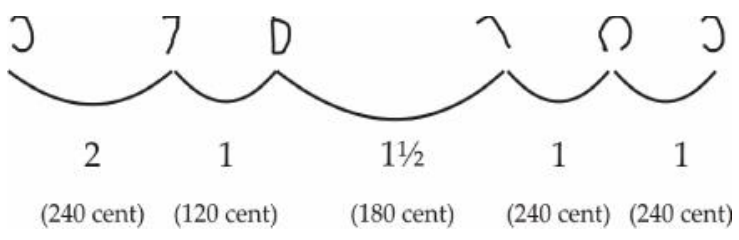

(Sumber : I Gusti Bagus Arsaja)

\section{Pengolahan}

Ugal, cecandetan, kotekan

Mengutip tulisan I Made Bandem, kesenian Bali yang sudah ada sejak zaman pra Hindu dan penulis Pande Made Sukerta yang mengatakan saat ini di Bali terdapat 33 (tiga puluh tiga) jenis perangkat gamelan. Gamelan ini memiliki titilaras,

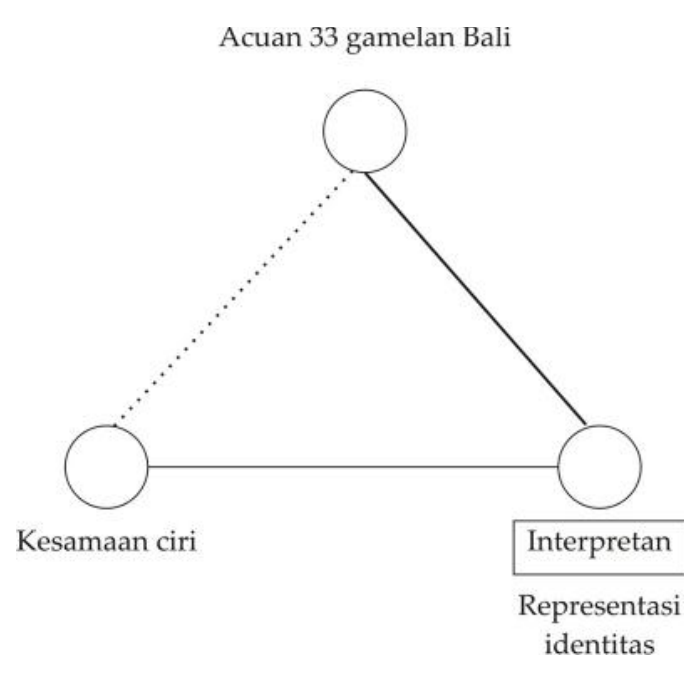

laras dan teknik menabuh yang sama, walaupun memiliki pengolahan yang berbeda, namun dari kesamaan unsurunsur musik tersebut menunjukkan representasi identitas. Jika dideskripsikan adalah sebagai berikut:

Mempertegas lagi pernyataan Eriksen bahwa identitas berupa penonjolan beberapa ciri-ciri, sementara ciri-ciri lain diabaikan.

Kesamaan pada unsur titilaras, laras, teknik menabuh yang menunjukkan representasi identitas etnik Bali.

\section{SIMPULAN}

Representasi dapat didefinisikan sebagai penggunaan tanda untuk menggambarkan sesuatu, yakni karakter musik, yang memiliki elemen, di antaranya teknik permainan dan garapan/ pengolahan. Sedangkan tanda adalah segala sesuatu (simbol) yang merepresentasikan sesuatu (nada dan irama dari etnik tertentu). Penampilan tanda-tanda yakni cengkok, imbal, diperlukan sebagai identitas yang merepresentasikan identitas etnik Jawa, begitu pula penampilan tanda-tanda yakni ugal, cecandetan, kotekan diperlakukan sebagai identitas yang mempresentasikan identitas etnik Bali. 


\section{Daftar Pustaka}

I Gusti Bagus Arsaja

1975 Metode Pendidikan Seni Karawitan Bali untuk Sekolah Menengah Pertama. Departemen Pen-didikan dan Kebudayaan Proyek Pendidikan dan Pembinaan Tenaga Teknik Kebudayaan.
I Made Bandem

1983 Ensiklopedi Gamelan Bali. Denpasar: Proyek Penggalian Seni Tradisional dan Kesenian Baru Pemerintah Daerah Tingkat I Bali. 